Dossiê: Conferência de Medellín: 50 anos - Artigo Original (c) $($ )

\title{
Medellín e Teologia da Libertação: muito mais que uma relação histórica
}

\author{
Medellín and Theology of the Liberation: more than a historical relationship
}

Agenor Brighenti*

\begin{abstract}
Resumo
Medellín e a Teologia da Libertação têm em comum um contexto social e eclesial marcado por profundas transformações, desafiando os cristãos a se somarem na busca de alternativas à situação de uma sociedade marcada pela injustiça institucionalizada e a exclusão. E tanto Medellín como a Teologia da Libertação foram duas respostas à altura, que dariam muito que falar, que pensar e que fazer. Medellín deu à Igreja na América Latina um rosto próprio, plasmado pelas comunidades eclesiais de base, a leitura popular da Bíblia, por uma Igreja pobre e para os pobres, pela pastoral social e os mártires das causas sociais. A palavra própria Ihe foi dada pela Teologia da Libertação, gestada em torno a Medellín, não só "uma nova maneira de fazer teologia" como "uma teologia nova", a primeira teologia na história da Igreja diferente da única teologia do centro e nascida na periferia.
\end{abstract}

Palavras-chave: Medellín; teologia; libertação; Igreja; sociedade.

\begin{abstract}
Medellín and Theology of Liberation share a social and ecclesial context marked by profound transformations, challenging Christians to gather together seeking for alternatives to the situation of a society characterized by an institutionalized injustice and exclusion. And both Medellin and Theology of Liberation were two apt answers, which would provoke too much talking, thinking and doing. Medellín gave a proper face to the Latin American Church, shaped by the so called Base Ecclesial Communities, the popular reading of the Bible, a poor Church for the poor, a social pastoral and martyrs of social causes. The word itself was given by Theology of Liberation, formed around Medellin, was not only "a new way of doing Theology", but "a new theology", the very first theology in Church history that was different from that one which was born in the centre, a theology that was born on the margins.
\end{abstract}

Key Words: Medellín; theology; liberation; Church; society.

Artigo submetido em 14 de abril de 2018 e aprovado em 28 de agosto de 2018.

* Doutor em Ciências Teológicas e Religiosas pela Universidade Católica de Louvain, Bélgica. Professor-pesquisador na PUC de Curitiba e professor-visitante no Instituto Teológico-Pastoral do Conselho Episcopal Latino-americano, em Bogotá. País de origem: Brasil. E-mail: brighenti.agenor@yahoo.com.br

Horizonte, Belo Horizonte, v. 16, n. 50, p. 544-575, maio/ago. 2018 - ISSN 2175-5841 


\section{Introdução}

Da mesma forma que não haveria Medellín sem o Vaticano II, não teria havido a Teologia da Libertação sem Medellín. Historicamente, ambos têm em comum um contexto social e eclesial marcado por profundas transformações, desafiando os cristãos a se somarem na busca de alternativas à situação de uma sociedade marcada pela injustiça institucionalizada e a exclusão. A "irrupção dos pobres" e do "terceiro mundo", os movimentos populares sob a repressão de sangrentas ditaduras militares; o idealismo e o utopismo reinante, em especial entre os jovens e intelectuais de classe média; as questões postas por jovens da Ação Católica inseridos profeticamente na sociedade, desafiavam respostas consequentes com os desafios de um momento histórico que não permitia esperar - "quem sabe, faz a hora" (Geraldo Vandré). Da parte da Igreja, Medellín e a Teologia da Libertação foram duas respostas à altura, posicionamentos corajosos, que dariam muito que falar, que pensar e que fazer, tanto que 50 anos depois continuamos falando, pensando e fazendo na perspectiva do caminho aberto e percorrido.

Mas, entre Medellín e Teologia da Libertação há uma relação muito mais que histórica, de contextos e desafios comuns assumidos e enfrentados. Como gostava de frisar J. Comblin, em Medellín, momento único na história da Igreja, magistério e teologia coincidiram. Em menor grau, o fenômeno tinha ocorrido no Vaticano II. $\mathrm{Na}$ América Latina, sintonizados com a renovação do Vaticano e consensuados na leitura dos "novos sinais dos tempos" presentes, magistério e teologia preparam, realizaram e assumiram as proposições de Medellín, que dariam a Igreja no continente um rosto e uma palavra própria.

O novo rosto, que fez a Igreja na América Latina deixar de ser uma "Igreja reflexo" da Igreja europeia, foi plasmado, entre outros, pelas comunidades eclesiais de base, a leitura popular da Bíblia, por uma Igreja pobre e para os pobres, a pastoral social e os mártires das causas sociais. A palavra própria lhe foi dada pela 
Teologia da Libertação, não só "uma nova maneira de fazer teologia” como "uma teologia nova”. A Teologia da Libertação é a primeira teologia na história da Igreja, plasmada diferente de uma única teologia do centro e, mais, nascida na periferia. Uma teologia, entretanto, nem por isso em ruptura com a tradição teológica da Igreja. João Paulo II, em Carta aos Bispos do Brasil, fala que a Teologia da Libertação "deve constituir uma nova etapa - em estreita conexão com as anteriores - da reflexão teológica" feita ao longo da história (Jỗo PAUlO II, 1986, p. 5). Juntamente com as duas Instruções da Congregação da Doutrina da Fé a respeito (Libertatis Nuntius e Libertatis Conscientia), apesar das ressalvas a determinadas "teologias da libertação", se admite "não só a oportunidade, mas a utilidade e a necessidade para toda a Igreja de uma verdadeira teologia da libertação" (JoÃo PAUlO II, 1986, p. 6).

É Medellín que vai dar à "nova teologia" suas categorias fundamentais, tais como: opção pelos pobres, pecado social, libertação integral; a unidade da história da humanidade e da salvação, a relação intrínseca entre evangelização e promoção humana; a salvação como passagem de situações menos humanas para mais humanas; a evangelização como processo de humanização; em resumo, a missão da Igreja é tornar presente a transcendência na imanência, a exemplo de Jesus Cristo que sendo rico se fez pobre para nos enriquecer com sua pobreza.

Por sua vez, a "nova teologia" nascida em torno a Medellín, enquanto "ato segundo" (a reflexão da práxis à luz da fé), precedido do “ato primeiro”, que são as práticas das comunidades eclesiais, inseridas profeticamente na sociedade, se constitui num serviço a Igreja e à sociedade. Uma teologia que não serve, não serve para nada, é sal que perdeu sua força. O "lugar natural" da "nova teologia" é a vida da comunidade eclesial. Com isso se afirma não só que a teologia é inseparável da consciência viva da Igreja, como ela é a inteligência reflexa da vida e da experiência de comunidades eclesiais concretas, inseridas profeticamente na sociedade. Sua função, como “ato segundo", é elevar o "grito dos pobres” ao conceito da fé, o momento teórico da vida e do agir dos cristãos no mundo. Sua originalidade está, 
não necessariamente em seu método ou em seu produto final, mas antes na experiência eclesial que a sustenta. O essencial do paradigma da Teologia da Libertação não é a teologia, mas a libertação, a experiência encarnada da fé. Por isso que a teologia, enquanto inteligência da fé só pode ser uma teologia em, desde e para o contexto desta experiência de fé. O “particular” da Teologia da Libertação que brota de Medellín, não está na teologia enquanto tal. Em última instância, a Teologia da Libertação inova em relação às teologias que a precederam por mudar de lugar e de função.

\section{Medellín-Teologia da Libertação: frutos de contextos comuns}

A Teologia da Libertação só nasceu porque a Igreja, sejam os bispos em Medellín, seja a comunidade teológica, estava inserida em seu contexto e sintonizada com seu tempo. Dez anos depois, nem Medellín e nem a Teologia da Libertação teriam sido possíveis. Do ponto de vista social, tanto Medellín como a "nova teologia" gestada em torno a ele, só foram possíveis graças à "década revolucionária" de 1960, marcada pela "irrupção dos pobres" e do "terceiro mundo", fruto da crise do "desenvolvimentismo" (SEGUNDO, 1978, p. 84). Desde a Encíclica Mater et Magistra, mas sobretudo com a Pacem in Terris, o Papa João XXIII já havia posto a Igreja nesta perspectiva, denunciando a sutileza de mecanismos neocolonizadores, que prolongavam a brecha entre hemisfério Norte e hemisfério Sul.

Do ponto de vista eclesial, Medellín e a Teologia da Libertação foram possíveis graças a buscas e realizações significativas, a começar pela Ação Católica especializada, particularmente a Juventude Agrária Católica (JAC), a Juventude Operária Católica (JOC) e a Juventude Universitária Católica (JUC), que já havia incidido sobre o Concílio Vaticano II, sobretudo no método de reflexão da Gaudium et Spes e na teologia do laicato (CONGAR, 1953). Na América Latina, foram os jovens da Ação Católica que tematizaram as principais questões relativas à vivência da fé no seio de uma sociedade marcada pela injustiça institucionalizada 
e a exclusão. Também foi dos quadros dos assistentes eclesiásticos da Ação Católica que veio grande parte dos bispos e teólogos da "geração-Medellín”, que se destacariam pelo seu preparo teológico-pastoral, liderança, testemunho de pobreza e presença pública da Igreja. Ao lado da Ação Católica, estavam também iniciativas como as comunidades eclesiais de base, os círculos bíblicos e o engajamento de cristãos na organização dos trabalhadores rurais, dos operários e na educação popular, na política, entre outros.

\subsection{0 contexto social}

A Teologia da Libertação se alicerça na virada de perspectiva na preparação da Conferência de Medellín, em sua primeira fase marcadamente desenvolvimentista, alinhada ao otimismo frente ao desenvolvimento e o progresso estampado na Gaudium et Spes, que a Populorum Progressio iria pontualizar e, em sua segunda fase, explicitamente libertadora, consciente que o subdesenvolvimento dos países subdesenvolvidos é um subproduto do desenvolvimento dos países desenvolvidos (GuTIÉRREZ, 1987, p. 228). Não se desconhece as grandes conquistas da modernidade, conquistas importantes, irrenunciáveis e universais, entretanto, constata-se que foram conquistas somente para uma parte da humanidade. Tomase consciência que o então denominado "terceiro mundo" ou os países do hemisfério Sul, ainda sob mecanismos neocolonizadores, tinha ficado à margem das benesses do desenvolvimento ocorrido no hemisfério Norte. Daí a "irrupção dos pobres", fruto da consciência de sua marginalidade e dependência em relação ao centro de um sistema excludente das maiorias, particularmente na América Latina (TAMAYO-ACOSTA, 1990, p. 31-33).

Uma análise social de tipo estrutural se encarrega de mostrar que o subdesenvolvimento dos países subdesenvolvidos não era um mero atraso histórico (G. Arroyo, 1972). Que além do conflito Leste-Oeste (coletivista marxista/liberalismo capitalista), havia um conflito Norte-Sul, entre países industrializados, detentores do poder sobre o capital, da tecnologia e das regras do

Horizonte, Belo Horizonte, v. 16, n. 50, p. 544-575, maio/ago. 2018 - ISSN 2175-5841 
mercado, e países dependentes, vítimas de mecanismos neocolonialistas. Consequentemente, em lugar de simplesmente abrir-se ao capital, à tecnologia e ao mercado do "primeiro mundo", o "terceiro mundo" precisava romper com a dependência, tal como acenava a "teoria da dependência”, elaborada pela Comissão Econômica para a América Latina-CEPAL (CARDOSO, 1979). A teoria demonstrava que, dentro do quadro das relações estabelecidas entre Norte e Sul, quanto mais desenvolvimento no Sul, mais dependência do Norte, sobretudo ao abrir-se à nova fase do capitalismo de então, que iniciava seu processo de globalização pela expansão das empresas multinacionais. Estas empresas traziam capital, tecnologia e mercado, mas se grande era a entrada de capital, maior era sua evasão, prolongando a sangria das "veias abertas da América Latina” (Eduardo Galeano). No contexto da época, tratava-se de um diagnóstico importante, pois, com isso se colocava as bases da passagem de uma postura desenvolvimentista, para uma perspectiva libertadora, que foi determinante para Medellín e para a gestação da Teologia da Libertação. Os cristãos tomam consciência que, à luz da fé, uma situação de opressão exige libertação e que, por sua vez, isso também diz respeito à salvação.

A nova consciência social desencadearia no Continente uma mobilização popular sem precedentes, com a participação de amplos segmentos da Igreja, clamando por profundas transformações. A adesão de segmentos de intelectuais das classes médias dava a impressão geral de que as mudanças não só eram possíveis como iminentes. Neste contexto, a "pedagogia do oprimido" de Paulo Freire contribui para o empoderamento das classes populares, levando os "oprimidos" a tomar de consciência de que a libertação de sua situação de opressão implica erradicar de dentro deles mesmos a introjecção do opressor, para tornarem-se sujeitos de seu próprio destino e agentes de uma nova sociedade (FREIRE, 1970). Em consequência, intensificam-se os trabalhos de educação popular, assim como de conscientização e formação política, que vão enriquecer também a Igreja. Toma-se consciência que uma evangelização integral passa também pela conscientização e a organização política. 
Mas, as mudanças não foram fáceis e nem rápidas. A “Aliança para o Progresso” de J. Kennedy seria substituída pela “Força Inter-americana de Paz” de L. Johnson, que patrocinou golpes militares em quase todos os países do Continente, levando a cabo uma sanguinária repressão da mobilização popular. Os militares respaldavam seus regimes de exceção na "Ideologia da Segurança Nacional" (Comblin, 1978), que se propunha defender a "civilização ocidental cristã", leia-se o sistema capitalista, da ameaça do ateísmo marxista. Nesta luta, todos os meios são justificáveis, independente de princípios éticos ou da declaração dos direitos humanos. Independência e libertação são vistas como portas abertas ao marxismo (Gomez DE SouzA, 1984). Mas, foi enfrentando a repressão e o martírio que a Igreja foi descobrindo sua missão de "defensora dos pobres e advogada da justiça”, companheira de caminho de toda a humanidade. Organizações como as "ligas camponesas", sindicatos de trabalhadores, movimentos estudantis e a educação popular, apoiados na "pedagogia do oprimido” de Paulo Freire, se encarregariam de dar organicidade à resistência.

A Conferência de Medelín esteve sintonizada com este contexto, graças a bispos inseridos na sociedade de seu tempo em perspectiva transformadora e com sensibilidade à causa dos pobres. Graças também a teólogos que buscam dar resposta, desde a fé, aos desafios oriundos de comunidades eclesiais inseridas no seio de uma sociedade marcadamente excludente das maiorias. Daí a postura profética e libertadora de Medellín, determinante para o surgimento da Teologia da Libertação.

\subsection{0 contexto eclesial}

Ao lado da "irrupção dos pobres" e do "despertar dos oprimidos" e do "terceiro mundo" no campo social, fator decisivo para o posicionamento profético de Medellín e o consequente surgimento da Teologia da Libertação no contexto eclesial, foi a presença ativa de setores significativos de cristãos em processos de libertação, seja na Igreja, seja na sociedade. Já desde a década de 1950, mas

Horizonte, Belo Horizonte, v. 16, n. 50, p. 544-575, maio/ago. 2018 - ISSN 2175-5841 
sobretudo na década de 1960, uma parte qualitativamente relevante da Igreja na América Latina faz sua a causa das maiorias oprimidas. Trata-se de cristãos geralmente militantes de Ação Católica especializada (JOC, JEC, JAC, JUC, principalmente) ou no caso do Brasil de agentes ou beneficiários do Movimento de Educação de Base (MEB), das Escolas Radiofônicas ou ainda de integrantes das primeiras Comunidades Eclesiais de Base. Desde meados de 1950, em contato com as ideias de Lebret e animados pela ação profética de Helder Câmara, toma-se consciência da necessidade de uma prática política e social na transformação da realidade nacional (ALVES, 1979, p. 124-125). A prática desses cristãos, geralmente da classe média junto aos movimentos populares, era sustentada pela teologia das realidades terrestres (G. Thils), o humanismo integral de J. Maritain, o personalismo social de E. Mounier, o evolucionismo progressista de Teilhard de Chardin, pela reflexão sobre a dimensão social dos dogmas de H. de Lubac, a teologia do laicado de Y. Congar, assim como pela reflexão de M. D. Chenu, ambos da Escola de Saulchoir (BOFF, L.-BofF, C., 1986, p. 95-96).

Como pano-de-fundo de todas estas iniciativas está a renovação do Vaticano II. Ao lado do turbilhão das transformações no campo social, nenhum acontecimento eclesial e nem todos juntos se equiparam ao significado e ao impacto do Concílio Vaticano II, do qual a Igreja na América Latina e o Caribe se propôs em Medellín fazer uma "recepção criativa" (Jon Sobrino). Todos nós conhecemos o papel que exerceram sobre o maior evento eclesial do século XX os movimentos de renovação bíblica, litúrgica, teológica, ecumênica, catequética, etc., graças à nova sensibilidade eclesial do Papa João XXIII (DusSEL, 1981, p. 70-78). Por um lado, o "Papa bom” se propõe levar a cabo um aggiornamento da Igreja em relação ao mundo moderno, frente ao qual se havia adotado uma postura apologética de cinco séculos. Por outro lado, João XXIII, de modo particular através de duas encíclicas sociais - Mater et Magistra (1961) e Pacem in Terris (1963), põe a descoberto as desigualdades entre hemisfério Norte e hemisfério Sul, não como uma fatalidade histórica, mas fruto de uma injustiça estrutural, que precisa ser urgentemente reparada, sob pena de acirrarem-se os conflitos 
mundiais. É nesta perspectiva que o Papa na convocação do Concílio vai falar da necessidade de “uma Igreja dos pobres, para ser a Igreja de todos”. Trata-se de um ideário que Paulo VI retomaria logo após o Concílio na encíclica Populorum Progressio, na qual qualifica o subdesenvolvimento dos países subdesenvolvidos como o subproduto do desenvolvimento dos países desenvolvidos (PP 8). Em sua denominada "volta às fontes" bíblicas e patrísticas, o Vaticano II constituiu-se no horizonte de uma arrojada renovação eclesial, que Medellín sou muito bem identificar e ser consequente, assim como a Teologia da Libertação. O Concílio fez uma ruptura radical com o eclesiocentrismo do catolicismo medieval e com o clericalismo e a romanização do cristianismo tridentino. Elaborou uma nova autocompreensão da Igreja numa postura de diálogo e serviço frente ao mundo, especialmente aos mais pobres.

Entretanto, por mais renovador que seja o Concílio, já no seu término, a Igreja na América Latina tinha a clara sensação de que o Vaticano II era um Concílio não só feito pela Igreja europeia, como em grande medida um Concílio mais para o "primeiro mundo" do que para o "terceiro mundo". Haviam ficado na penumbra questões importantes como as causas da pobreza no mundo, a relação entre evangelização e promoção humana, a forma de presença da Igreja e dos cristãos na sociedade, a legitimidade de uma Igreja autóctone, a necessidade de um pluralismo teológico e disciplinar, Igreja e profetismo, etc. Dar resposta a estas questões pendentes, é ao que Medellín irá propor-se com sua "recepção criativa” do Vaticano II, num continente marcada pela injustiça institucionalizada e a exclusão.

Como elementos do contexto eclesial de Medellín e que estão na gênese da Teologia da Libertação, poderíamos ainda nomear as iniciativas e práticas das comunidades eclesiais de base, pioneiras em São Paulo e Fortaleza (Brasil), San Miguelito (Panamá), Riobamba (Equador) ou Santiago do Chile, já em 1962 presentes no Plano de Pastoral da Conferência dos Bispos do Brasil (CNBB). Não esquecendo também da pessoa do Papa Paulo VI, por sua influência na convocação de Medellín, de quem Mons. Manuel Larraín e Dom Hélder Câmara eram muito 
próximos, assim como a influência na agenda da Conferência da publicação da Populorum Progressio (GuTIÉRREZ, 1987, p. 228), sem esquecer a presença do Papa Paulo VI na inauguração da Conferência, aludindo em seu Discurso Inaugural à "nova era” que a Igreja na América Latina estava iniciando, o que contribuiu para o clima de liberdade e responsabilidade autóctone, que reinou durante os trabalhos da Conferência de Medellín.

Também não se pode deixar de nomear toda uma geração de teólogos jovens, formados nas melhores universidades europeias, não só sintonizados com o Concílio Vaticano II, mas sobretudo com as questões levantadas pelos cristãos inseridos no social. Encontros para discernir e buscar possíveis respostas começaram ainda durante o Concílio, como foi o caso da reunião de teólogos latinoamericanos, realizada em Petrópolis (Brasil), em março de 1964, seguida das reuniões de Havana, Bogotá e Cuernavaca em 1965 e das reuniões de Montreal e Chimbote (Peru) em 1967. Muitos destes teólogos estavam ligados à Conferência Latino-americana de Religiosos (CLAR), que até meados da década de 1970, pôde trabalhar estreitamente com o Conselho Episcopal Latino-americano - CELAM (HOUTART, 1975).

Finalmente, cabe assinalar que sujeito eclesial de forte influência em Medellín foi a Ação Católica, que não só havia levado a Igreja inserir-se profeticamente no mundo e suscitado toda uma geração de bispos e presbíteros comprometidos com os pobres, como também está na gênese da articulação de uma palavra própria da Igreja na América Latina - a teologia da libertação. Conforme atesta L. A. Gomes de Souza, quando Gustavo Gutiérrez estava elaborando a obra pioneira - Teologia da Libertação, Perspectivas -, que inauguraria um discurso da fé no qual a libertação é afirmada como categoria fundante da teologia, por duas vezes interrompeu seus trabalhos no Peru e veio ao Brasil para discutir determinadas questões com grupos de Ação Católica, especialmente com jovens ligados à JUC no período entre 1960-1963 (GOMES DE SOUZA, 1984, p. 9). Tanto que sua obra pioneira está dedicada ao Pe. Henrique Pereira Neto, assessor da JUC e de 
Dom Hélder Câmara, na arquidiocese de Olinda e Recife. Tal como atestam vários registros históricos, os movimentos de Ação Católica como um todo no Brasil, em especial a JUC, foram "uma espécie de laboratório das novas relações entre fé e política" (ANTOINE, 1971, p. 65). Na realidade, a JUC de 1960 vivia antecipadamente no Brasil, "a efervescência do cristianismo revolucionário, que outros países como Argentina, Uruguai, Colômbia e Chile só conheceriam entre 1968-1970" (RICHARD, 1978, p. 130).

\section{Em torno a Medellín, o surgimento de uma "nova teologia".}

É comum aos teólogos latino-americanos ligados à Teologia da Libertação se remeterem, com frequência, a alguns missionários e bispos luso-hispânicos, sobretudo do século XVI, como os inspiradores da perspectiva libertadora de Medellín e como os precursores da "nova teologia" (TAMAYO-ACOSTA, 1990, p. 2529). Nomes como Bartolomeu de las Casas, Antônio de Montesinos, Antônio Valdivieso, Antônio Vieira, Frei Caneca, etc. fazem parte do imaginário dos evangelizadores durante os cinco séculos do itinerário da Igreja no continente, em cuja tradição profética a Teologia da Libertação tem suas raízes históricas (BoFF, L.-BofF, C., 1986, p. 93). Há inclusive os que vão mais longe e veem na conversão de Bartolomeu de las Casas o nascimento da Teologia da Libertação (DUSSEL, 1979). O fato é que a tradição crítico-profética na Igreja latino-americana e a luta pela vida e pela liberdade de indígenas, negros, mestiços das populações pobres tem nele um referencial paradigmático.

\subsection{A gestação ou o tempo de preparação (1962-1968)}

A gestação da Teologia da Libertação se insere na atmosfera teológica marcada pela grande liberdade de debate e de criatividade por ocasião da realização do Concílio Vaticano II, 1962-1965 (BofF, L.-BofF, C., 1986, p. 96-97). O evento não significou somente o re-situar da Igreja no mundo e sua reconciliação com o mundo moderno, como também, através da constituição Gaudium et Spes, inaugurou uma maneira diferente de ler a realidade ou os "sinais dos tempos", a 
partir da trilogia do método "ver-julgar-agir" da JOC, já anteriormente assumida pelo Magistério pontifício na Mater et Magistra (SCANNONE, 1987, p. 22). Além do mais, a realização do Concílio propiciou, de um lado, o conhecimento mútuo e o crescimento da consciência de unidade continental entre pastores e teólogos latinoamericanos e, de outro, incentivou os teólogos a pensarem as próprias questões pastorais, sem o costumeiro mimetismo em relação à teologia europeia. Começaram a proliferar os encontros entre teólogos para aprofundar, sobretudo, a relação entre fé e política, evangelho e justiça social, questões estas postas pelos cristãos engajados na sociedade autônoma, sobretudo ligados ou oriundos da Ação Católica (BofF, L.-BofF, C., 1986, p. 97).

A primeira reunião de teólogos latino-americanos, nesta perspectiva, teve lugar em Petrópolis (Brasil), em março de 1964, seguida das reuniões de Havana, Bogotá e Cuernavaca, em 1965, e das reuniões de Montreal e Chimbote (Peru), em 1967. Outras se seguiram no imediato pós-Medellín: de 6 a 7 de março de 1970 celebra-se em Bogotá o primeiro congresso sobre Teologia da Libertação, repetido no mesmo lugar de 26 a 31 de julho de 1971. Do lado protestante, o ISAL (Igreja e Sociedade na América Latina), entre 1970 e 197,1 organiza também, em Buenos Aires, algo semelhante (BoFF, L.-BoFF, C., 1986, p. 96-98).

Dada a importância do primeiro encontro, de 1964 em Petrópolis, convém assinalar alguns aspectos que determinaram o rumo das demais reuniões e reflexões do grupo. Entre os estudos apresentados na ocasião, destacam-se os textos de Gustavo Gutiérrez (GuTIÉRREZ, 1964) e, sobretudo, o texto de Juan Luís Segundo (SEGundo, 1964, p. 74-82). Este, de forma indutiva, num primeiro momento faz uma análise da realidade do continente, para, em seguida, tecer algumas considerações teológicas em termos de iluminação da realidade analisada, para desembocar, por fim, em três propostas pastorais concretas. Ainda que de forma embrionária e velada já se vislumbram, a nível epistemológico, as três mediações teóricas da nova teologia, que iria nascer no imediato pós-Medellín - a mediação das ciências humanas e sociais, a mediação hermenêutica e a mediação 
da práxis. Quanto a G. Gutiérrez, na oportunidade ele caracterizava a teologia como "uma reflexão crítica sobre a práxis, à luz da fé”, colocando assim as bases do novo método da Teologia da Libertação e sua nova maneira de teologizar.

Mas, é sobretudo em torno à preparação da II Conferência Geral dos Bispos da América Latina e Caribe, realizada em Medellín no ano de 1968, que aparecem as intuições básicas e os grandes eixos temáticos da Teologia da Libertação. Os múltiplos encontros de preparação haviam sido verdadeiros laboratórios para uma teologia pensada a partir das questões oriundas do engajamento dos cristãos numa sociedade marcada pela injustiça institucionalizada e a exclusão das maiorias (Boff, L.-Boff, C., 1986, p. 97). Por volta de 1967 e 1968, precedidos por documentos pastorais, começam a surgir os primeiros artigos, nos quais se utiliza explicitamente a dinâmica do método ver-julgar-agir na reflexão teológica, tal como os bispos haviam feito em Medellín, tanto na reflexão como na redação dos dezesseis documentos. Nestes, aparece a busca de uma nova perspectiva teológica, elaborada de maneira indutiva, tal como o Magistério havia feito a leitura dos “sinais dos tempos" na Gaudium et Spes. Hugo Assmann iria ainda mais longe, afirmando que esse ponto de partida - a realidade ou os "sinais dos tempos' - não pode limitar-se a algo abstrato como a "dignidade humana" ou a "vocação à liberdade". O ponto de partida, assinala ele, deve ser uma "análise estrutural da sociedade" (ASSMANN, 1968, p. 17).

Toda essa reflexão vai influenciar diretamente a preparação de Medellín, que inicialmente se baseava sobre esquemas desenvolvimentistas. A reunião de Mar del Plata de 1966, que celebrava a $\mathrm{X}^{\mathrm{a}}$. Assembleia Ordinária do Conselho Episcopal Latino Americano (CELAM) é prova disso. Se, por um lado, essa assembleia marca a recepção por parte do episcopado latino-americano da perspectiva desenvolvimentista, por outro, sentia-se que ela não tinha o consenso de todos, como se veria na realização da Conferência. Medellín, ao buscar receber de forma criativa o Vaticano II na América Latina, não só fazia uma leitura dos "sinais dos tempos” presentes no continente, como também buscava responder ao desafio da 
pobreza da maioria de sua população. Com isso, se impunha à consciência de um número cada vez maior de bispos, teólogos e cristãos engajados que a Igreja, inserida num mundo subdesenvolvido, deveria urgentemente ser a Igreja de todos, particularmente a Igreja dos pobres, conforme o ideário de João XXIII (CHENU, 1977, p. 73-79).

Os documentos de Medellín ainda que registrem certas arestas a polir, por um lado, refletem a conhecida "fidelidade criadora" em relação ao Concílio Vaticano II, na medida em que o acolhem não de forma mimetista, mas com maturidade e originalidade (SOBRINO, 1985, p. 105-134). Por outro lado, temas como "violência", "justiça", "paz", "pobreza", "promoção humana", etc., ocupam especial relevância no texto final, em parte fruto da influência de Populorum Progressio, publicada no ano anterior. Expressões como "libertação de toda situação opressiva", "situação de pecado", "violência institucionalizada", "mudança de estruturas", "conscientização", "educação libertadora" e outros presentes nos documentos conclusivos, marcam a recepção da temática dependência-libertação e a rejeição, ainda que parcial, dos esquemas desenvolvimentistas (DUSSEL, 1981, p. 70-78).

\subsection{A gênese da "nova teologia" (1969-1971)}

O surgimento da Teologia da Libertação é o resultado da confluência de dois movimentos desencadeados na América Latina na década de 1960. De um lado, o engajamento de segmentos cristãos na sociedade em perspectiva transformadora, principalmente da Ação Católica, procurando serem consequentes com sua fé e, de outro, a busca de uma nova reflexão sistemática por parte de teólogos, que iluminasse a prática desses cristãos e que desse resposta à situação de dependência do continente (TAMAYO-ACOSTA, 1990, p. 53-54).

Historicamente, alguns passos merecem destaque. A partir de 1964, em plena realização do Concílio, um grupo de teólogos e pastoralistas latinoamericanos se dá conta que a teologia elaborada na América Latina é uma 
reprodução mimética da teologia europeia. Propõe-se, então, forjar uma reflexão teológica que tome como ponto de partida a situação de dependência e de dominação, não somente da América Latina, mas de dois terços da humanidade (TAMAYO-ACOSTA, 1990, p. 54). Neste particular, jogou um papel importante a mediação das ciências humanas e sociais na apreensão da realidade (MALDONADODUSSEL, 1975, p. 54-56), especialmente a sociologia e a economia, as quais a partir de 1964, tinham passado da sócio-economia do desenvolvimento à "teoria da libertação", através do diagnóstico da "teoria da dependência". Segundo esta perspectiva, a situação de pobreza do "terceiro mundo" é fruto de um desequilíbrio crescente e estrutural entre o "centro" e a "periferia" de um sistema econômico, que faz com que o subdesenvolvimento dos países pobres seja o subproduto do desenvolvimento dos países ricos.

Persuadidos da pertinência de tal teoria, alguns grupos de teólogos de vários países latino-americanos tomam consciência de que o método teológico europeu não é adequado para a América Latina. A realidade particular do continente não permite que a teologia latino-americana seja simplesmente reprodução mimética da teologia europeia. Impõe-se, com urgência, se não se quiser cair no "cinismo" (ASSMANN, 1973, p. 40), a elaboração de um discurso teológico com uma metodologia original que dê resposta, a partir da fé, sobretudo aos desafios sócioeconômicos, políticos, culturais e religiosos do continente, em resumo, à questão da pobreza estrutural.

É justamente neste período de recepção de Medellín, que havia assumido estas intuições básicas, que vão aparecer as reflexões embrionárias da Teologia da Libertação. Por exemplo, Gustavo Gutiérrez contrapõe uma "teologia da libertação" à uma "teologia do desenvolvimento" (GuTIÉRREZ, 1968), da mesma forma que Richard Schaull (SchAull, 1968) e Rubem Alves (AlveS, 1968). Lúcio Gera se contrapõe às teologias da secularização, da revolução e da "morte de Deus" (GERA, 1970). Hugo Assmann marca a diferença entre uma teologia da libertação e a teologia da esperança (ASSMANN, 1973). Outros como Enrique Dussel (DussEL, 
1973) e Juan Carlos Scanonne (SCANONNE, 1971) dão à nova teologia um apoio histórico-filosófico e epistemológico, respectivamente. Várias revistas de teologia publicam importantes contribuições também nesta linha ${ }^{1}$.

Entretanto, enquanto reflexão sistematicamente articulada, a Teologia da Libertação só surgiria com o primeiro congresso sobre Teologia da Libertação no imediato pós-Medellín, realizado em Bogotá em 1970 e repetido no ano seguinte no mesmo local. Após esses congressos, apareceriam as obras pioneira de Gustavo Gutiérrez (GuTiÉRrez, 1971), Hugo Assmann (AssmanN, 1971) e Leonardo Boff (BOFF, 1972). Dentre eles é, sem sombra de dúvida, Gustavo Gutiérrez quem apresenta a primeira proposta orgânica de uma Teologia da Libertação e quem encontra para ela uma formulação definitiva (SCANNONE, 1987, p. 25). A sua obra Teologia da Libertação, Perspectivas - tem o mérito de transformar o conceito de libertação numa categoria fundante de um sistema teológico. A Teologia da Libertação nascente se autocompreende não como uma teologia do genitivo, uma teologia temática, em que a libertação é um tema ligado à teologia moral, mas uma teologia fundamental que relê de maneira indutiva, ou seja, a partir da situação histórica de uma América Latina dependente e dominada, a globalidade da Mensagem revelada (TAMAYO-ACOSTA, 1990, p. 57). Ela se autocompreende como uma omniteologia ou uma teologia completa. É neste sentido que G. Gutiérrez fala de "uma teologia nova' e de "um novo modo de fazer teologia", uma vez que a práxis libertadora é tomada como uma nova perspectiva hermenêutica. Trata-se de uma teologia não somente com função crítica da ação pastoral da Igreja, mas como "a reflexão crítica da práxis histórica à luz da Palavra" (GuTIÉRREZ, 1972, p. 38). Uma reflexão crítica "na" e "sobre" a práxis histórica em confronto com a Palavra (SCANnONE, 1987, p. 25). Teologia "da" Libertação: o "da" se explica "na" e "sobre", no sentido que a libertação ou a práxis histórica não é somente o objeto da reflexão, como explicita também o lugar desde "onde" e "a partir de onde" ela se articula, com uma implicação para o sujeito da mesma (GuTiÉRREZ, 1972, p. 36). A teologia é

\footnotetext{
${ }^{1}$ Destacam-se Stromata (Buenos Aires), Teología y Vida (Santiago), Christus (México), Pastoral Popular (Chile), Revista Eclesiástica Brasileira - REB (Petrópolis-Brasil), SIC (Caracas), Diálogo (Panamá), Víspera (Montevidéu), Servicio de Documentación del MIEC (Lima).
}

Horizonte, Belo Horizonte, v. 16, n. 50, p. 544-575, maio/ago. 2018 - ISSN 2175-5841 
compreendida, assim, como "ato segundo", precedido pelo "ato primeiro" que é a práxis da libertação. É o que mais tarde se chamaria de "passo zero" ou de "momento pré-teológico", que supõe o engajamento ou a "experiência espiritual do pobre" da parte do teólogo, uma vez que a reflexão teológica não toma a práxis simplesmente como tema ou objeto, mas como lugar epistêmico. Sem esta "síntese viva com a prática viva", o teólogo não reúne as condições epistemológicas adequadas para fazer teologia (BOFF, C. 1990, p. II). Porém, como reflexão crítica da práxis, esse "novo modo de fazer teologia" não substitui as funções tradicionais da teologia como "sabedoria espiritual" e como "saber racional e científico", mas as pressupõe e necessita, assim como as complementa e permite uma nova compreensão delas (SCANNONE, 1987, p. 26). Tudo isso, tinha muito a ver com as intuições básicas e eixos fundamentais de Medellín.

\subsection{A fase de crescimento (1972-1979)}

Nascida em torno a Medellín, a Teologia da Libertação cresceu e se desenvolveu até à Conferência de Puebla (1979) em condições pouco favoráveis, pois desde 1972, acabada de nascer, estaria marcada pelo "cativeiro" e pelo "exílio". O fervor profético emanado de Vaticano II e de Medellín e que encontrara eco em muitos cristãos engajados e teólogos, logo enfrentaria reações, tanto a nível da sociedade civil, como da instituição eclesial.

No campo social, em 1964 dá-se o golpe militar e se instala a ditadura no Brasil, em 1971 no Uruguai, em 1972 na Bolívia e em 1973 no Chile. Muitos foram os teólogos e pastores expulsos de seus lugares de trabalho em seus próprios países ou perseguidos pela própria Igreja (MALDONADO, 1975, p. 58-61). No âmbito eclesial, neste período, o CELAM muda radicalmente de perspectiva. Na Assembleia de Sucre, acontecida em novembro de 1972, com a nomeação de A. Lopes Trujillo para a Secretaria Geral, decide-se pelo fechamento do Instituto de Pastoral em Quito, do Instituto de Liturgia em Medellín e do Instituto de Catequese em Manizales, para concentrá-los todos na cidade de Medellín (HOUTART, 1975, p. 
10-24). Na sequência, numa reunião em Bogotá em novembro de 1973 (CELAM, 1974) e por ocasião do congresso de Teologia da Libertação realizado em Toledo, em 1974, o CELAM pronuncia-se abertamente e contrariamente em relação à Teologia da Libertação (CELAM, 1974) e, consequentemente, em relação à Medellín.

Entretanto, é em meio a controvérsias e perseguições que a Teologia da Libertação terá o seu período de maior criatividade, principalmente no campo da epistemologia e do método. A esse respeito convém evocar alguns acontecimentos significativos, a começar pelo primeiro encontro de Teologia da Libertação no El Escorial (Espanha) de 8 a 15 de julho de 1972, sob o tema - Fé cristã e mudança social na América Latina -, que reuniu teólogos latino-americanos com alguns outros europeus, particularmente espanhóis (OLIVEROS, 1990, p. 36). Na oportunidade partilhou-se o teor e o método do pensamento teológico no seio da nascente teologia latino-americana em relação à teologia europeia (EL ESCORIAL, 1973). Em 1974, outro evento de importância foi a publicação de um número especial da revista Concilium, dedicado inteiramente à Teologia da Libertação, o que contribuiu decisivamente para a sua afirmação no panorama teológico mundial. Em 1975, de 11 a 15 de agosto, teve lugar no México, o Encontro Latinoamericano de Teologia, centrado sobre o método da Teologia da Libertação, visto como fruto da inspiração de Vaticano II e de Medellín, tido como um método de teologizar consequente com os desafios da realidade do continente (MALDONADO, 1975). Na sequência, veio o encontro de Detroit, realizado de 18 a 24 de agosto de 1975, que marca o início de um profícuo processo de colaboração entre os cristãos em luta pela libertação nos Estados Unidos e na América Latina, especialmente a nível ecumênico.

Fato significativo no desenvolvimento da Teologia da Libertação foi o Sínodo dos Bispos de 1974, através do qual a Igreja na América Latina faz chegar à Igreja universal as intuições básicas e eixos fundamentais de Medellín. Paulo VI, na publicação da Exortação Evangelii Nuntiandi, acusa recepção de categorias como 
libertação, comunidades eclesiais de base, inculturação, os laços intrínsecos entre evangelização e promoção humana, justiça e transformação social, ainda que sem fazer referência explícita a Medellín e à teologia latino-americana (Paulo VI, 1975, n. 31). Na sequência, o encontro de teologia realizado em Dar es Salaam, de 5 a 12 de agosto de 1976, foi outro acontecimento significativo para o crescimento da Teologia da Libertação. Ele reuniu importantes teólogos da Ásia, África e América Latina, marcados pelo colonialismo e a opressão, dando início ao fecundo trabalho da Associação dos Teólogos do Terceiro Mundo². Por fim, não se pode deixar de citar a convocação e o processo de preparação, realização e recepção da Conferência de Puebla (1979). Tendo como um dos objetivos a avaliação da Conferência de Medellín, a sua preparação suscitou um intenso trabalho teológico, que contribuiu grandemente para aprofundar e ampliar a leitura de Medellín e a reflexão da Teologia da Libertação. Os estudos e as contribuições das Igrejas locais e nacionais tiveram grande peso em Puebla, ainda que não pela via dos documentos oficiais de preparação da Conferência, meticulosamente controlados pelos ares de “involução eclesial” que se havia instalado no CELAM e muito bem acolhidos em segmentos da Cúria romana, com a chegada de João Paulo II e o então Cardeal J. Ratzinger.

Entre os avanços mais importantes no campo da reflexão teológica neste período (1972-1979), destacam-se, entre outros: a tematização do "não-homem" e não o "não-crente" como o interlocutor da Teologia da Libertação; a leitura da Bíblia a partir dos pobres, em perspectiva popular; a releitura da história desde a ótica dos oprimidos ou do "reverso da história"; os pobres como sujeitos e mediadores privilegiados do Reino; o resgate do Jesus histórico, Jesus de Nazaré como Libertador; uma espiritualidade poiada numa contemplação na ação; a situação de opressão-libertação como "ponto de partida" da reflexão teológica, porquanto prolonga a paixão de Jesus no mundo; as comunidades eclesiais de base como "célula inicial da estruturação eclesial", etc. (OLIVEROS, 1990, p. 37-40). No

\footnotetext{
${ }^{2}$ Outras importantes reuniões da Associação são a do Brasil (1980), Índia (1983), México (1986).
} 
campo da explicitação da epistemologia e do método da Teologia da Libertação, destacam-se os estudos de J. B. Libânio (LiBÂNiO, 1977, p. 27-79), Juan Carlos Scanonne (SCANONNE, 1977, p 10-16) e, sobretudo, a contribuição de Clodovis Boff (BOFF, C. 1976), que dá à teoria teológica da libertação um estatuto epistemológico e metodológico próprio.

Entretanto, sem dúvida é a Conferência de Puebla o evento maior na linha de consolidação da epistemologia e do método da Teologia da Libertação, apesar das tensões em seu processo de preparação e realização. De maneira explícita, as conclusões finais reafirmam que todo compromisso pastoral brota de um discernimento da realidade (CELAM, 1979, n. 28-30) e que, a missão da Igreja é evangelizar em perspectiva libertadora, em vista da construção de uma nova sociedade pluralista (CELAM, 1979, n. 1206), a partir dos pobres (CELAM, 1979, n. 190), sacramento do Reino definitivo na história.

\subsection{A fase de consolidação (1979-1985)}

O período de consolidação da Teologia da Libertação se poderia situar entre Puebla (1979) e a publicação, em 1986, da segunda Instrução da Congregação da Doutrina da Fé sobre a Teologia da Libertação, intitulada Libertatis Conscientia. A consolidação da "nova teologia”, surgida na esteira de Medellín, deu-se em meio a polêmicas, marcada também por suspeitas, desconfiança e ataques (OLIVEROS, 1990, p. 43). Do lado dos teólogos ligados à nova teologia nascente, procura-se fundamentar sua identidade e método, situá-la no seio da tradição teológica da Igreja e justificar a leitura da globalidade da Mensagem revelada, a partir de uma perspectiva particular, mas não parcial (BoFF. L-BofF. C., 1986, p. 162) - a opção pelos pobres e a dimensão libertadora da fé -, que está implícita na fé cristológica, tal como afirmou Bento XVI no Discurso Inaugural de Aparecida. Do lado dos setores mais preocupados com a ortodoxia da fé do discurso teológico, acusa-se a "nova teologia" de reduzir a totalidade do mistério da fé à dimensão libertadora (CABRAl DUARTE, 1984, p. 28-29) e, portanto, trata-se de uma teologia reducionista. 
É neste período, porém, que se explicitará melhor a epistemologia e o método da Teologia da Libertação em relação à teologia clássica escolástica e a teologia moderna europeia. Mostra-se que a primeira procura responder a perguntas "da fé para a fé", de forma dedutiva e essencialista, enquanto que a segunda, embora se articule a partir de perguntas de caráter mais existencial e de modo indutivo, fica ainda no âmbito da antropologia, sem tirar as consequências da fé para o contexto atual. Já a Teologia da Libertação, na interrelação da práxis com a fé, de forma dialética, procura responder ao desafio de como ser cristão num continente marcado pela opressão (LiBÂNIO, 1980, p. 118-126). Frente a isso, não faltou quem acusasse a nova teologia que, ao "partir da práxis libertadora na ótica do oprimido", não passava de um discurso sociologizante ou mesmo de um racionalismo teológico, de uma teologia sem Deus (KLOPPENBURG, 1985, p. 33-34). Entretanto, se pronunciando pela necessidade de um discurso da fé, apoiado numa racionalidade histórica e contextual, articulado a partir da realidade apreendida pela mediação das ciências humanas e sociais, seguida de um "julgar" a realidade analisada à luz das Escrituras e da Tradição, para desembocar em um "agir" cristão consequente com os desafios oriundos da práxis (LiBÂNIO, 1980, p. 122). Não sem dificuldades, o diálogo com a teologia moderna europeia pouco a pouco iria tecendo laços enriquecedores para ambos lados, diferente do posicionamento de segmentos do magistério, que acusam a Teologia da Libertação de perder de vista a metafísica, dado que ao partir da práxis da fé e ao assumir, portanto, um procedimento indutivo, situa-se no particular, eclipsando o universal (KlOPPENBURG, 1985, p. 33-34) e, com isso, rompe com a catolicidade da fé.

A questão mais polêmica, entretanto, seria a do uso do marxismo como mediação analítica na apreensão da realidade. Do lado da Teologia da Libertação, argumenta-se que certos teólogos fazem uso apenas instrumental do materialismo histórico (a ciência do marxismo), tomando-se distância do materialismo dialético (a filosofia do marxismo), que é ateu e que, portanto, deve ser rejeitado (LiBÂNIO, 1980, p. 124-125). Em contraposição, objeta-se a análise "dialético-estrutural" pode conduzir a uma prática político-social contrária ao pensamento social cristão, na 
medida em que limita a realidade social ao nível estrutural (econômico, político, social). Aplicada à pastoral, dizem, este tipo de análise pode levar a identificar o Reino de Deus com um projeto de construção de uma sociedade terrena (FREIRE FALCÃO, 1983, p.12-23). É em meio a esta controvérsia que em 1984 é publicada a primeira Instrução da Congregação para a Doutrina da Fé, intitulada Libertatis Nuntius. Na introdução, frisa que sua razão de ser é chamar a atenção dos pastores, teólogos e de todos os fiéis, entre outros, para os desvios e perigos para a fé e para a vida cristã, presentes em determinadas formas de Teologia da Libertação que usam, segundo o documento, de maneira insuficientemente crítica, conceitos assumidos de diversas correntes do pensamento marxista (RUIZ, 1984, p. 439-452).

Entre os segmentos que fizeram larga recepção da Instrução Libertatis Nuntius afirma-se, em geral, que o documento não pretende ser um desestímulo à participação ativa na obra de promoção humana, uma vez que o documento não critica a opção preferencial pelos pobres, mas o caráter ideológico desta opção, que nega o amor evangélico (MORENO, 1984, p. 333-342). Seu objetivo, continuam eles, é corrigir os vários desvios doutrinários em que incorrem os teólogos da libertação nos aspectos hermenêutico, antropológico e sociológico, ético ou moral, exegético, dogmático, cristológico e eclesiológico. Segundo eles, os mais graves são os desvios hermenêuticos e dogmáticos. O princípio hermenêutico escolhido pelos teólogos da libertação é a práxis marxista, que desemboca na luta de classes. Na cristologia, Cristo é reduzido a um libertador político e, na eclesiologia, a Igreja se restringe a uma organização do povo oprimido que luta pela libertação política (DE MIRANDA, 1985, p. 196-211).

Do lado dos segmentos ligados à Teologia da Libertação, ao contrário, a recepção do documento não foi nada positiva. Mesmo que se reconheça que o documento pode se aplicado a determinadas elaborações teóricas que levam o nome de "teologia da libertação", mas que não são reconhecidas nem pelos teólogos da libertação, discorda-se do tom pessimista do documento que, na prática, parece dirigir-se contra todas as "teologias da libertação" e, ao mesmo tempo, a nenhuma 
delas (PASTOR, 1986, p. 77-86). Critica-se, sobretudo, a visão caricatural que o documento tem do marxismo, do qual elemento central é tido como sendo a luta de classes elevada a lei fundamental da história. Segundo estes, o tema da libertação é abordado de modo diverso do modo como é feito no seio da Teologia da Libertação. $\mathrm{Na}$ Instrução, ele é teórico, na Teologia da Libertação ele é vivência concreta. Um dos teólogos mais representativos da "nova teologia" constata que a Instrução não chega a ver o caráter estrutural da vida humana. Ela é incapaz de pensar o social socialmente (LORSCHEIDER, 1984, p. 700-708).

Bem mais positiva foi a publicação, pela mesma Congregação, de uma segunda Instrução, em 1986, intitulada Libertatis Conscientia que, na prática, apresenta um esboço de uma autêntica "teologia da libertação". Sua recepção foi bem mais positiva. Ressalta-se nos meios eclesiais ligados à "nova teologia”, que a Instrução segue o método ver-julgar-agir, ainda que o "ver" apresente a realidade de maneira genérica, restrito à aspiração à liberdade por parte dos povos, analisando-a cultural e filosoficamente. No Documento a Teologia da Libertação é entendida como o encontro entre a aspiração à liberdade e o tema bíblico da liberdade e não como o discurso de um Deus que se revela como Amor numa realidade marcada pela pobreza e pela opressão (PALÁcıO, 1985, p. 293-323). Colocados à parte esses limites, se reconhece que o significado maior da segunda Instrução está na acolhida da questão da libertação dos oprimidos (BOFF, L.-BoFF,

C., 1986, p. 251-262) como uma realidade também teológica. A noção de "libertação", ainda que parta da libertação soteriológica para chegar à libertação histórico-social, perpassa todo o mistério da Salvação (BOFF, C. 1986, p. 263-271).

\section{A Teologia da Libertação: realmente um "começo" novo?}

A "nova teologia", nascida em torno a Medellín, que muda de "lugar" e de “função", articulada de numa relação dialética entre fé e práxis e que introduz a opção pelos pobres como fio condutor, será que realmente, é um “começo” novo? 
Em seus primórdios, os teólogos ligados à “nova teologia” faziam questão de colocar em relevo que o método da Teologia da Libertação é uma "ruptura epistemológica" em relação aos métodos das grandes teologias da tradição da Igreja. Não tanto com a Teologia Patrística, mas sobretudo, em ruptura com o método dedutivo da teologia clássica escolástica, que enquanto scientia de Deo ou fides quaerens intellectum, pelo método da analogia fidei articula as auctoritates e a ratio, para dar uma resposta à pergunta da fé para a fé (LiBÂNIO, 1989, p. 84-87). Em ruptura também com o método via de regra indutivo da teologia moderna europeia que, enquanto se articula a partir das perguntas postas pela razão autônoma e pela experiência, através do método auditus fidei, elabora uma teologia positiva, limitando-se a buscar a ordem sucessiva da história da comunicação e da explicitação no tempo das verdades reveladas (LiBÂNIO, 1989, p. 90-94). Em descontinuidade com estas, a Teologia da Libertação se articula a partir de um método nem dedutivo nem indutivo, mas, precisamente dialético, fruto da interrelação entre imanência e transcendência, na medida em que tem seu "ponto de partida" na "experiência de Deus no pobre" (Boff, C., 1990, p. IV). Seu ponto de partida é a fé, é certo, mas como esta se dá na experiência, a "nova teologia" "parte de Deus partindo do pobre ou parte do pobre partindo de Deus" (ibid.), estabelecendo, de um lado, uma distinção entre teologia, Revelação e Fé e, de outro, uma relação indissociável ou de interpenetração entre estes três fatores, na medida em que a norma da Fé (norma normans) é a Palavra de Deus, proclamada e vivida na Igreja que peregrina na concretude da história. Mas, será que a relação da Teologia da Libertação com as teologias que a precederam é realmente uma relação de "ruptura"? E se este é o caso, é possível uma teologia autenticamente eclesial, sem estar apoiada na tradição viva da Igreja, espaço onde foram elaboradas as grandes sínteses teológicas do passado?

A resposta a estas questões passa pela busca das raízes da epistemologia e do método desta "nova maneira de fazer teologia". Ao mergulhar no emaranhado de iniciativas e tematizações que compõem as origens da Teologia da Libertação, se constata que seus teóricos não consideram o "novo" de sua teologia como 
originário do nada. Desde os seus primórdios, eles a situam no seio da Tradição da Igreja, como uma leitura atualizadora da Palavra revelada, tradição viva do conhecimento e da experiência que vem acumulando interpretações ao longo dos séculos. Trata-se de uma "nova teologia”, mas não necessariamente de um "começo novo”. Ao contrário, sua relação com a longa tradição teológica da Igreja é de apropriação, de assimilação metabólica, não de maneira paralela e justaposta, mas sob a forma de uma síntese teórica que se realiza através da produção de um "novo sentido" do velho, situado em um novo contexto. A relação entre o sentido de ontem e o sentido de hoje, segundo seus teóricos, não se estabelece pela via da afirmação e da negação, mas pela via da "superação dialética dos sentidos", num processo de continuidade/descontinuidade. Assim, a "nova teologia" inova, sim, mas apoiada na longa tradição da Igreja.

É verdade que, historicamente, diante dos ataques desqualificadores por parte de alguns teólogos de outras teologias, seus teóricos haviam acentuado mais a "ruptura epistemológica" em relação às demais teologias do que sua "continuidade" ou "superação dialética". Entretanto, uma vez afirmada a consistência da "nova teologia”, ao caracterizar seu método, seus teóricos passaram a associá-lo ao método de Gaudium et Spes (BoFf, L., 1976, p. 37-38), posteriormente assumido por Medellín e transformado em regra epistemológica da "nova teologia". Afirmam que existe na Teologia da Libertação "ruptura epistemológica", mas que ela é relativa. Mais do que "ruptura" epistemológica, o método da "nova teologia" é concebido como "refundição" epistemológica dos métodos das teologias anteriores. E mais que isso, passam a reconhecer que o método da Gaudium et Spes, na verdade, se apoia sobre o método ver-julgar-agir da Ação Católica (BoFF, C., 1976, p. 27), assumido por Medellín, não só como momentos estruturantes dos seus dezesseis documentos, como também método de reflexão. De fato, grande parte dos bispos e teólogos atores na Conferência de Medellín eram oriundos da Ação Católica, enquanto assessores ou "assistentes eclesiásticos” (GOMEZ DE SOUZA, 1984).

Horizonte, Belo Horizonte, v. 16, n. 50, p. 544-575, maio/ago. 2018 - ISSN 2175-5841 
Como vimos, a Teologia da Libertação tem suas origens nos acontecimentos em torno a Medellín (GUTIÉRREZ, 2010, p. 273-252). Nesta Conferência, os bispos vão tematizar e explicitar algumas das mais significativas categorias da teologia latino-americana (OLIVEROS, 1990, p. 35-36). Medellín vai dar à Igreja no Continente um rosto próprio, superando os limites de uma "Igreja reflexo" (H. Lima Vaz) do eurocentrismo imperante e, em sua esteira, a Teologia da Libertação dará a ela uma palavra própria (MCGRATH, 1998, p. 89-122). Entre Medellín e Teologia da Libertação, há uma relação histórica e uma relação epistemológica. E da mesma forma que Medellín ao inovar não rompe com a Vaticano II do qual faz uma "recepção criativa", a Teologia da Libertação inova apoiada em Medellín, mas sem romper com a longa e rica tradição teológica da Igreja.

\section{Conclusão}

Poucos poderiam imaginar que 50 anos depois, tanto Medellín como a Teologia da Libertação guardam toda sua relevância e atualidade. Por um lado, isso revela que ambos tocaram realidades essenciais implicadas na Mensagem cristã, que somado à qualidade como foram tematizadas, continuam referenciais imprescindíveis para os cristãos empenhados em tornar presente o Reino de Deus numa sociedade marcada pela injustiça institucionalizada e por exclusões de toda índole. Em Medellín, magistério e teologia convergiram na busca de uma resposta consequente com os ideais da fé cristã, aos desafios oriundos de um mundo de crucificados, que prolongam a paixão de Jesus na paixão do mundo. E como tanto Medellín como a Teologia da Libertação se apoiam sobre a renovação do Vaticano II, a relevância de ambos reafirmam igualmente a atualidade do Concílio, que Aparecida e o Papa Francisco têm resgatado não sem resistências e mesmo oposição dos que fazem do passado um refúgio, em meio às instabilidades de nosso tempo.

Por outro lado, se é verdade que a situação dos pobres, infelizmente, tem mudado muito pouco nestes últimos 50 anos, e daí a relevância e atualidade tanto Medellín como a Teologia da Libertação, o mundo dos pobres mudou muito. E 
mudado o contexto, mudam as perguntas, obrigado a dar novas respostas. Na fidelidade às intuições básicas e eixos fundamentais do Vaticano II, urge fazer uma "segunda recepção" do Concílio no novo contexto em que vivemos. Da mesma forma, os novos tempos desafiam uma "segunda recepção" tanto de Medellín como da Teologia da Libertação, como de certa forma o fazem Aparecida e o magistério do Papa Francisco na Evangelii Gaudium. No âmbito da teologia latino-americana, desafio especial é o imperativo de teologizar a partir das matrizes das epistemologias do Sul, acolhendo a decolonização como novo "sinal dos tempos", revelado pelas subjetividades vulneráveis e vulneradas, situadas no "reverso da história”.

\section{REFERÊNCIAS}

ALVES, M. A Igreja e a política no Brasil. São Paulo: Loyola, 1979.

ALVES, Rubem. Towards a Theology of liberation. Princeton: Theological Seminary, 1968.

ANTOINE, Charles. L’Église et le pouvoir au Brésil. Paris: Desclée, 1971.

ARROYO, Gonzalo. Pensamiento latino-americano sobre el desarrollo y la dependencia externa. In: Instituto Fe y Secularidad, Fe cristiana y transformación social en América latina. Encuentro de El Escorial, 1972.

ASSMANN, Hugo. La situación histórica de dependencia y dominación de dos tercios de la humanidad. Teología desde la praxis de la liberación, Ensayo teológico desde la América dependiente. Salamanca: Sígueme, 1973. (Coleção Agora).

ASSMANN, Hugo. Opresión-liberación: desafío de los cristianos. Montevideo: 1971.

ASSMANN, Hugo. Tarefas e limitações de uma teologia do desenvolvimento. Vozes, n. 62, p. 13-21, 1968.

ASSMANN, Hugo. Teología desde la praxis de la liberación. Salamanca: Sígueme, 1973 .

ASSMANN. Hugo. Aporte cristiano al proceso de liberación, AA.VV. Movilización popular y fe cristiana. Motevideo: ISAL, 1971.

ASSMANN. Hugo. Teología de la liberación. Montevideo: JECI, 1970.

Horizonte, Belo Horizonte, v. 16, n. 50, p. 544-575, maio/ago. 2018 - ISSN 2175-5841 
BEOZZO, José Oscar. Cristãos na Universidade e na Política. Petrópolis: Vozes, 1984.

BOFF, Leonardo. Jesus Cristo Liberador. Petrópolis: Vozes, 1972.

BOFF, L.; BOFF, C. Como fazer Teologia da Libertação. Petrópolis: Vozes, 1986.

BOFF, Clodovis. Retrato dos 15 anos da Teologia da Libertação. REB, n. 182, 263-271, 1984.

BOFF, Clodovis. Teologia e Prática. A Teologia do Político e suas mediações. Petrópolis: Vozes, 1978.

BOFF, Clodovis. Théorie et Pratique, La méthode des théologies de la libération. Paris: Les Éditions du Cerf, 1990. (Coleção Cogitatio Fidei, 157).

BOFF, L.; Cl. BofF, C. Convocatória geral em prol da Libertação - Carta aberta ao Cardeal Prefeito da Congregação para a Doutrina da Fé. REB, n. 182, p. 251-262, 1986.

BOFF, Leonardo. Teologia do cativeiro e da libertação. Lisboa:Multinova, 1976.

CABRAL DUARTE, Dom Luciano José. Reflexões sobre a Teologia da Libertação.

Boletim da Revista do Clero, p. 28-29, abril 1984.

CARDOSO, Fernando Henrique-FALETTO, Enzo. Dependencia y desarrollo en América Latina. México: Siglo XXI, 1969.

CARDOSO, F. H. Teoria da dependência ou análises concretas de situações de dependência. Estudos CEBRAP, São Paulo, n. 1, 1979.

CELAM. Documento de Puebla. Bogotá: Centro de Publicaciones, 1979.

CELAM. Liberación: diálogos en el CELAM. Bogotá: Centro de Publicaciones, 1974.

CELAM. Teología de la Liberación: Conversaciones de Toledo. Bogotá: Centro de Publicaciones, 1974.

CHENU, Marie Dominique. La Iglesia de los pobres en el Vaticano II. Concilium, n. 124, p. 73-79, 1977.

COMBLIN, José. A ideologia de segurança nacional. O poder militar na América Latina. Rio de Janeiro: Civilização Brasileira, 1978.

CONGAR, Yves. Jalons pour une théologie du laïcat. Paris: Cerf, 1953.

CONGREGAÇÃO PARA A DOUTRINA DA FÉ. Instrução Libertatis conscientia sobre a liberdade cristã e a libertação. In: CNBB (Ed.). Instruções sobre a Teologia da Libertação. São Paulo: Paulinas, 1986. (Coleção Documentos e Comentários 3). 
CONGREGAÇÃO PARA A DOUTRINA DA FÉ. Instrução Libertatis nuntius sobre alguns aspectos da Teologia da Libertação. In: CNBB (Ed.). Instruções sobre a Teologia da Libertação. São Paulo: Paulinas, 1986. (Coleção Documentos e Comentários 3).

DE MIRANDA, A. A. Desvios ou equívocos doutrinários da Teologia da Libertação. Communio, n. 4, p. 196-211, 1985.

DUSSEL, E. Para una ética de la liberación latino-americana. Tomos I-II. Buenos Aires: Ed. Caros Lohlé, 1973.

DUSSEL, Enrique. De Medellín a Puebla, una década de sangre y esperanza. México: Ed. Edicol, 1979.

DUSSEL, E. De Medellín a Puebla. Uma década de sangue e esperança I. De Medellín a Sucre, 1968-1972. São Paulo: Ed. Paulinas, 1981, p. 70-78.

EL ESCORIAL. Fe cristiana y cambio social en América Latina. Encuentro de El Escorial. Salamanca: Sígueme, 1973.

ELLACURÍA, Ignacio-SOBRINO, Juan (Org.). Mysterium Liberationis: conceptos fundamentales de la Teología de la Liberación. Tomo I, Madrid: Editorial Trotta, 1990.

FREIRE FALCÃO, José. Análise dialético-estrutural. Communio, n. 7, p. 12-23, 1983.

FREIRE, Paulo. A pedagogia do oprimido. Rio de Janeiro: Paz e Terra, 1970.

GERA, Lúcio. Cultura y dependencia a la luz de la reflexión teológica. Stromata, n. 1-2, tomo 30, p. 179, 1974.

GERA, Lúcio. La Iglesia debe comprometerse en lo político. Montevideo: JECI, 1970.

GOMEZ DE SOUZA, Luiz Alberto. A JUC: os estudantes e a política. Petrópolis: Vozes, 1984 .

GOMEZ DE SOUZA, Luiz Alberto. JUC: os estudantes católicos e a política. Petrópolis: Vozes, 1984.

GUTIÉRREZ, Gustavo. A atualidade de Medellín. In: Conclusões da Conferência de Medellín - 1968. Trinta anos depois, Medellín ainda é atual? São Paulo: Paulinas, 2010. p. 273-252.

GUTIÉRREZ, Gustavo. Hacia una Teología de la Liberación. Lima: CEP, 1969.

GUTIÉRREZ, Gustavo. La pastoral de la Iglesia en América Latina. Lima: CEP, 1968. 
GUTIÉRREZ, Gustavo. La recepción del Vaticano II en América Latina. In G. ALBERIGO; J.P. JossuA (Ed.). La recepción del Vaticano II. Madrid: Cristiandad, 1987.

GUTIÉRREZ, Gustavo. Ponencia (I Reunión de Teólogos latinoamericanos

celebrada en Petrópolis en 1964). Lima: Centro Bartolomé de las Casas, 1964. Mimeo.

GUTIÉRREZ, Gustavo. Teología de la Liberación. Lima: Perspectivas, 1971.

GUTIÉRREZ, G. Teología de la Liberación. Salamanca: Sígueme, 19712.

HOUTART, François. Le Conseil Épiscopal d'Amérique latine accentue son changement. ICI, n. 481, p. 10-24, Paris, 1975.

JOÃO PAULO II. Carta aos Bispos do Brasil. REB, Petrópolis, n. 182, p. 396-402, 1986.

KLOPPENBURG, Boaventura. A nova maneira de fazer teologia. Boletim da Revista do Clero, Rio de Janeiro, p. 33-34, setembro, 1985.

LIBANIO, João Batista. A volta à grande disciplina: reflexões teológico-pastorais sobre a atual conjuntura de Igreja. São Paulo: Loyola, 1993.

LIBANIO, João Batista. Metodologia da Teologia da Libertação. Teocomunicação, Porto Alegre, n. 48, p. 118-126, 1980.

LIBANIO, João Batista. Teología de la Liberación, Guía didáctica para su estudio, Santander: Sal Terrae, 1989.

LIBANIO, João Batista. Teologia no Brasil, reflexões crítico-metodológicas. Perspectiva Teológica, Belo Horizonte, n.178, p. 27-79, 1977.

LORSCHEIDER, Aloísio. Observações a respeito da Instrução sobre Alguns Aspectos da Teologia da Libertação. REB, Petrópolis, n. 176, p. 700-708, 1984.

MALDONADO, Enrique (Org.). Liberación Y cautiverio, debates en torno al método de la teología en América Latina, Encuentro latinoamericano de Teología. México: Dabar, 1975.

MCGRATH, Marcos. Vaticano II-Medellín. Iglesia de los pobres y teología de la liberación. Cuestiones teológicas y filosóficas, Panamá, n. 63, p. 89-122, 1998.

MORENO, F., El Vaticano y la Teología de la Liberación. Theologica Javeriana, Bogotá, n. 510, p. 333-342, 1984.

OLIVEROS, Roberto. Historia de la Teología de la Liberación. In: ELLACURÍA, Ignacio SOBRINO, Jon. Mysterium Liberationis - Conceptos fundamentales de la Teología de la Liberación. Madrid: Editorial Trotta, 1990, p. 35-45. 
PALÁCIO, Carlos. A Igreja da América Latina, a Teologia da Libertação e a Instrução do Vaticano. Um discernimento. Perspectiva Teológica, Belo Horizonte, n. 438, p. 293323,1985 .

PASTOR, Félix. Gnose marxista e Teoria Cristã, Análise da Instrução Romana sobre a Teologia da Libertação. Perspectiva Teológica, Belo Horizonte, n. 41, p. 77-86, 1986.

RICHARD, P. Mort des chrétientés et naissance de i'église. Paris : Centre Lebret, 1978.

PAULO VI. Evangelii Nuntiandi. São Paulo: Paulinas, 1975.

RUIZ, L. La Congregación para la Doctrina de la fe y su concepto sobre el Marxismo. Theologica Xaveriana, Bogotá, n. 4, p. 439-452, 1984.

SCANNONE, Juan Carlos. El actuial desafio planteado al lenguage teológico latinoamericano de liberación. CIAS, Buenos Aires, n. 211, p. 5-20, 1972.

SCANNONE, Juan Carlos. Hacia una dialética de la liberación. Stromata, Buenos Aires, n. 17, p. 23-6o, 1971.

SCANNONE, Juan Carlos. La reflexión teoria-práxis en la Teología de la Liberación. Christus, México, n. 499, p. 10-16,1977.

SCANNONE, Juan Carlos. Ontología del processo auténticamente liberador. AA.VV. Panorama de la teología latinoamericana. Salamanca: Seladoc, 1975.

SCANNONE, Juan Carlos. Teología de la liberación y doctrina social de la Iglesia. Madrid: Ed. Cristandad; Buenos Aires: Editorial Guadalupe, 1987.

SCATENA, Silvia. In populo pauperum: La chiesa latino-americana dal Concilio a Medellín (1962-1968). Bolonha: Società Editrice il Mulino, 2008.

SCHAULL, Richard. Consideraciones teológicas sobre la liberación del hombre. IDOC, Bogotá, n. 43, 1968.

SCHAULL, Richard. La liberación humana desde la perpectiva teológica. Mensaje, Madrid, n. 168, p. 175-179, 1968.

SEGUNDO, J. L. Libertação da teologia. São Paulo: Loyola, 1978.

SEGUNDO, Juan Luis. Liberación de la teología. Buenos Aires; México: Ed. Caros Lohlé, 1975.

SEGUNDO, Juan Luis. Pastoral latinoamericana: hora de la decisión. Mensaje, Madrid, n. 127, p. 74-82, 1964. 
SOBRINO, Juan. El Vaticano II y la Iglesia latinoamericana. In: C. FLORISTÁN y J.-J. TAMAYO (Ed.). El Vaticano II, veinte años después. Madrid: Cristiandad, 1985. p. 105-134.

TAMAYO-ACOSTA, Juan José. Para comprender la Teología de la Liberación. Navarra: Editorial Verbo Divino, 1990. 